\title{
Increasing of down passing skills for mini volleyball game by using reciprocal teaching model
}

\author{
Syamsuar Abbas ${ }^{1}$, Reflianto ${ }^{2}$ \\ ${ }^{1}$ Universitas Negeri Padang, Padang - Indonesia, (syamsuar90@gmail.com) \\ ${ }^{2}$ Universitas Negeri Malang, Malang - Indonesia, (refliantomuslim@gmail.com)
}

\begin{abstract}
The aim of this study was to increase students' down passing skill for miny volleyball game at class of elementary school by using reciprocal teaching model. Reciprocal teaching model can increase the activity of students in participating to the teacinglearning process. The implementation of this model gave a positive impact on the students' agility and physical fitness particularly for increasing students' down passing skill in the game of mini volleyball. This study used a research and development method. Subjects of this study were fifth grade students from elementary. The result of this result reported that by using reciprocal teaching model can improve students' down passing skill in the playing of Mini Volleyball game and enhyances students' physical fitness and health as well as master with basic technique of the mini volleyball game. Sport education teacher could use this model to Elementary students level for improving their down passing skill in the game of mini volleyball.
\end{abstract}

Keywords: Down passing skills, mini volleyball, reciprocal teaching model

\section{Introduction}

In order to improve the education quality has been carried out, either through the development of quality teachers, Education process for various facilities supporting the education process. Physical Education curriculum should be able to provide a learning experience consciously through physical activity, where students can develop the skills concept and attitudes necessary for a healthy and productive life (Dougiierty, N., \& Bonanno, 1979). If the physical education program is an intregal part of the education curriculum as a whole, it must be able to stimulate the three domains of cognitive domain objectives, namely cognitive, affective and psychomotor domain (Bloom, 1956).

Physical education and health also play a role in backing wake of student character. Sports activities are very nice especially in distributing and developing students' potency. Potential students include talent, motivation, co-operation of the team, hard work, respect a success and how to face defeat. This indicates that the physical and health education in schools can provide overall benefits that are both physically and mentally on the students.

Physical education and health are the medium to promote physical, mental growth, mental growth, motor skills, knowledge and reasoning, appreciation of the value (emosional-mental attitude 
of sportsmanship-spiritual-social), as well as habituation healthy lifestyle that is geared to stimulate physical growth and psychological development qualities are balanced.

One of the efforts in the implementation of the physical education program in elementary school is to adjust the childrens' world. Physical education process tailored to the child's developmental level, well adapted to the level of childrens' physiological development and social without departing from the Education predetermined. Students tend to perform motion in physical education, only when the teacher noticed or when there is a task to perform an exercise, and even then limited to a given task, without any effort to train skills of motion, making it better or flexible in performing a movement technique.

Teaching is a process of knowledge or skills from students' master. The substance of teaching space includes not only knowledge but also skills in the broad sense that is skills for life skills, values and attitudes. Therefore (Briggs., 1977) defines learning as a process of behavioral changes including changes in the human tendencies such as attitudes, interests, values and abilities that change the ability improvement to do the performance. Changes in behavior need to be able to survive in a given time period. Learning can basically be viewed as a process of qualitative positive changes that occur in the students' behavior as subjects of learners due to increase the knowledge, skills, values, attitudes, interests, appreciation, the ability to think logically and critically, interactive capabilities and creativity that has been achieved.

The learning process is effective if the internal and external factors of the student is observed by every teacher. Internal factors include the talent, intelligence (intellectual, emotional, and spiritual), interests, motivations, attitudes and social and cultural backgrounds. External factors include learning objectives, learning materials, strategies and methods of teaching, learning media, classes organizing, reinforcement, the social climate in the classroom, the time allocation, systems and engineering evaluation, the views and teachers' attitudes towards students and teachers attempt to address students' learning difficulties.

In connection with the learning process it is necessary to approach, appropriate learning strategies in the learning process of Physical Education. Many learning model has developed by the experts, even some of the teachers have developed in order to improve the quality of learning in schools. A variety of learning models will create a fun learning environment for students, as well as learning outcomes can provide a useful meaning for the students themselves, except it can be motivating for teachers to improve their profesionalism in terms of learning. That there is no single model of learning is better than learning model to another. Best learning model is most suited to the characteristics of learners, objectives, teaching materials, tools / media, time available, circumstances and conditions.

During this time PE teachers in teaching only use the command method, lectures, assignments, and demonstrations. On the results just so there is a significant change and it requires a long time to achieve maximum results. Meanwhile, there is a learning method according to new research, actually although the method is a merge of the existing method by adding a little more humane and reciprocal approach. Reciprocal methods is a learning method that priority to dialoque between teachers denngan students, between students and students, and in dialoque the two-way communication means to provide feedback or opinions from the activities, so that the position between teachers and students here balanced.

One of the subjects of Physical Education in primary schools in 2004 competency-based curriculum is a game of volleyball mini. Mini volleyball games began to be taught in grade IV, V and VI Elementary School. This game is very suitable to be developed as one of the subjects of Physical Education in Primary Schools as it can promote the development of basic movement skills and student movements, such as running, jumping and hitting. 
Mini volleyball games loaded with movements of running, jumping and hitting well in an effort to attack the opponent or defend against an opponent. Similarly, it will develop such as increased physical ability, improve and promote physical fitness, laid the foundation of moral character that is strong through the internalization of values, build a foundation of strong personality, social attitudes and tolerance, fostering the ability to think critically, develop sportsmanship, honesty, discipline , responsible, cooperative, confident and able to fill leisure time with creative activities.

Basically Down Passing is a key base in a game of volleyball, then down passing is the absolute to be ruled by all the players. Mastery of basic techniques are perfectly will enable to be achieved by doing the exercises, a continuous exercisesa and a good training method. Mastery of basic technique as one of supporting the success of mini volleyball games. Learning mini volleyball games for elementary students, especially passing under the right choice for a teacher with fifth grade stduents because they have been able to follow the volleyball teaching given by the teacher (Yunus, 1992)

\section{Method}

This research method is Research and Development with Triangulation Mixed Method Design. According to the type of research that developed by research development. The procedure following studies. Creswell W John (2014) set research and development research procedures consists of steps as follows: (1) explore the potential problems, (2) data collection, (3) products design, (4) validation design, (5) the revised design, (6) products test, (7) revision of the product, (8) testing utility, (9) the revision of the product, and (10) the mass production. To better clarify the research steps, following the steps presented image on the research and development, The subject of research was conducted on students fifth grade of Elementary School of Koto X Singkarak subdistrict of Solok Regency. Subjects of this study were fifth grade students from elementary schools of Koto X Singkarak sub district in Solok Regency as much as 19 students. Instrument of this research used questionaire, field notes, observation sheet, motoric skill test for measureing students' skill in doing the down passing at the time playing of mini volleyball game and focus group discussion to enhance the practical reciprocal teaching model in its implementation to the field.

\section{Results and Discussion}

The components are validated at this stage including elements of the model, the learning device and developmental instrument as research instruments. Prototype that have been revised and then to be reassembled based on the results of the validation and revisions have already been made before.

Furthermore, the tests on the fith student grade of Elementary School Koto X Singkarak subdistrict of Solok Regency. The process of testing carried out aimed to find the weaknesses or deficiencies of the learning device in getting a number of inputs for the improvement of learning tools that researchers have developed.

Researchers carried out the tests on the students fifth grade of Elementary School, the schedule has been designed in such a way. In connection with the implementation of learning the subject of mini volleyball games that lasted for 4 months with the number of students 19 and one teacher observer. 
Table 1. Result of Student Activity Analysis

\begin{tabular}{cccccc}
\hline Group & Students' Score & \multicolumn{2}{c}{ First Treatments } & \multicolumn{2}{c}{ Second Treatments } \\
\cline { 3 - 6 } & & Value & Category & Value & Category \\
\hline \multirow{3}{*}{1} & Student 1 & 35 & Very Good & 3.9 & Very Good \\
\cline { 2 - 6 } & Student 2 & 33 & Very Good & 3.6 & Very Good \\
\cline { 2 - 6 } & Student 3 & 27 & Good & 3.4 & Good \\
\hline \multirow{3}{*}{2} & Student 4 & 39 & Very Good & 3.8 & Very Good \\
\cline { 2 - 6 } & Student 5 & 34 & Good & 3.4 & Good \\
\cline { 2 - 6 } & Student 6 & 28 & Good & 3.7 & Very Good \\
\hline & Average & 32.67 & Good & 36.33 & Very Good \\
\hline
\end{tabular}

Based on the table 1 can be seen that the implementation of the trial in the class, one teachers observe two groups of students with many members in one group of 3 students. Students' activities observed was started by learning students' acitivities in their group in the class. Analysis of this finding sowed that in the first Treatments to the first and second group there were two students more actived and ithe second group just one students being more activied in the first experiemnt but two students was more actived in second Treatments and other students just actived. It means that the activiities of students during study by using reciprocal model both the first and second experimen was effective. Teachers' activities during teacing -learning process in the class can be seen from the data of result finding as follows :

Table 2. Result of Teacher and Observer Activity Analysis

\begin{tabular}{cccccccc}
\hline \multirow{2}{*}{ Group } & $\begin{array}{c}\text { Stages of } \\
\text { Teacing }\end{array}$ & \multicolumn{3}{c}{ First Treatments } & \multicolumn{3}{c}{ Second Treatments } \\
\cline { 2 - 7 } & Observer & Result & Category & Observer & Result & Category \\
\cline { 2 - 7 } & Preliminary & Observer & $88.88 \%$ & & Observer & $100 \%$ & \\
\cline { 2 - 7 } & & Teacher & $100 \%$ & & Teacher & $100 \%$ & \\
\hline \multirow{2}{*}{2} & Average & $94.44 \%$ & Effective & Average & $100 \%$ & Effective \\
\cline { 2 - 7 } & Core & Observer & $93.93 \%$ & & Observer & $96.97 \%$ & \\
\cline { 2 - 7 } & Activities & & & & & & \\
\cline { 2 - 7 } & & Teacher & $87.80 \%$ & & Teacher & $93.93 \%$ & \\
\hline 3 & Average & $90.90 \%$ & Effective & Average & $95.45 \%$ & Effective \\
\hline & Clossing & Observer & $100 \%$ & & Observer & $100 \%$ & \\
\hline & Teacher & $100 \%$ & & Teacher & $100 \%$ & \\
\hline
\end{tabular}

Based on the table 2 above can be seen that teachers' activities druing the teaching learning process have been running in the class was relatively effective where in every stages of learning all participant was more eager to followed the study. It menas that the activity of teacher during the teaching learning process have been running well in the class by using reciprocal teaching model. For students achievement from 19 students involved in teacing-learning process bothy in first Treatments and second Treatments in the class by using reciprocal teaching model can be obtained by using achivement test with following result :

Table 3. Student Achievement

\begin{tabular}{ccccc}
\hline Learning Outcomes Category & \multicolumn{2}{c}{ First Treatments } & \multicolumn{2}{c}{ Second Treatments } \\
\hline & Score & Category & Score & Category \\
\hline Average of students' learning outcome & $92.58 \%$ & Good & $94.05 \%$ & Good \\
\hline Absorbtion & $92.58 \%$ & Good & $94.05 \%$ & Good \\
\hline Mastery Learning & $100 \%$ & Excellent & $100 \%$ & Excellent \\
\hline Average & $95.00 \%$ & Good & 96.03 & Excellent \\
\hline
\end{tabular}


Rerefered on the table 3 above can be reported that students' achivement both in the first and second Treatment after analysis of the achievement based three category namely students' learning outcome, absorbtion of subject and mastery learning showed that all criteria in the successfull category with two in the good category and one in the excellent category with range of students' achievement ranking between from $92.58 \%$ to $100 \%$ completed. The optimalization of student activities in the motoric skill to the first Treatment by involving 19 students who given achievement test to measure their skill in doing the down passing movement at the time of playing the mini volleyball game can be seen on the table below:

Table 4. The optimalization of Students' Activities In Mastering of Motoric Skill of Down Passing at the Time of Playing the Mini Volleyball Game

\begin{tabular}{ccccccc}
\hline Score & \multicolumn{3}{c}{ First Treatments } & \multicolumn{3}{c}{ Second Treatments } \\
\hline & Frequency & Percentage & Category & Frequency & Percentage & Category \\
\hline $33-37$ & & - & - & 8 & $42.11 \%$ & Very Good \\
\hline $28-32$ & 10 & $52.63 \%$ & Very Good & 9 & $47.37 \%$ & Very Good \\
\hline $23-27$ & 5 & $26.32 \%$ & Good & 2 & $10.53 \%$ & Good \\
\hline $18-22$ & 4 & $21.05 \%$ & Enough & 0 & - & - \\
\hline $13-17$ & 0 & - & - & 0 & - & - \\
\hline $8-12$ & 0 & - & - & 0 & - & - \\
\hline
\end{tabular}

Rerefered on the table 4 above can be reported that from 19 students involved in the following of Students' Activities Test to measure their Motoric Skill Achievement of Down Passing at the Time of Playing the Mini Volleyball Game showed that ten students of them had high-level motoric skills of Down Passing when playing the Mini Volleyball Game with percentage of 52.63\% in the category of very good, and then about five of other students had the fair level with percentage of $26.32 \%$ in the category of good and the rest just got in the fair level with percentage of $21.05 \%$ in the category of enough. While in the second Treatments showed that students' motoric skill of Down Passing when playing the Mini Volleyball Game with percentage of $89.47 \%$ in the category of very good, and then about two of other students had the fair level with percentage of $10.53 \%$ in the category of good. Here, the second Treatments was better result after improvement strategy from first Treatment before.

Practical Reciprocal teaching model to measure the effective model in inproving students' Motoric Skill Achievement of Down Passing at the Time of Playing the Mini Volleyball Game was done by fifth grade students from elementary schools of Koto X Singkarak sub district in Solok Regency as much as 19 students. From nineteen students who observed based on Motoric Skill Achievement of Down Passing in Playing the Mini Volleyball Gam about 15 student said teaching by using Reciprocal teaching model can make them easier and practical to to respon teachers' explanation about the true technique of down pasisng in playing of volleyball game and just four students had negative response about the Reciprocal teaching model that they followed whent doing the exercises of down passing technique in the plaing of volleyball game subject.

The effectiveness of reciprocal teaching model in the classroom measured by using questionaire to know the students' responses about the practicing of this model in the classroom toward their inquiry, eager and motivation to follow the teaching learning process in the class besides considering the result of the real observation in the field. The analysis of reciprocal teaching model effectiveness can be explaned based on the table 5 below: 
Table 5. The Effectiveness Analysis of reciprocal teaching model in Classroom by Teacher and Observer

\begin{tabular}{|c|c|c|c|c|c|c|c|}
\hline \multirow{2}{*}{ No } & \multirow{2}{*}{ Criteria } & \multicolumn{3}{|c|}{ First Treatments } & \multicolumn{3}{|c|}{ Second Treatments } \\
\hline & & Evaluation & Result & Category & Evaluation & Result & Category \\
\hline \multirow[t]{3}{*}{1} & \multirow{3}{*}{$\begin{array}{l}\text { Validity (These } \\
\text { models assess student } \\
\text { learning during the } \\
\text { learning process in the } \\
\text { classroom) }\end{array}$} & Observer & $87.50 \%$ & & Observer & $91.66 \%$ & \\
\hline & & Teacher & $91.66 \%$ & & Teacher & $95.83 \%$ & \\
\hline & & Average & $89.58 \%$ & Effective & Average & $93.75 \%$ & $\begin{array}{c}\text { More } \\
\text { Effective }\end{array}$ \\
\hline \multirow[t]{3}{*}{2} & \multirow{3}{*}{$\begin{array}{l}\text { Reliability (This model } \\
\text { can always be used in } \\
\text { each study) }\end{array}$} & Observer & $95.58 \%$ & & Observer & $95.00 \%$ & \\
\hline & & Teacher & $95.00 \%$ & & Teacher & $100.0 \%$ & \\
\hline & & Average & $95.00 \%$ & $\begin{array}{c}\text { More } \\
\text { Effective }\end{array}$ & Average & $97.50 \%$ & $\begin{array}{c}\text { More } \\
\text { Effective }\end{array}$ \\
\hline \multirow[t]{3}{*}{3} & \multirow{3}{*}{$\begin{array}{l}\text { Objective (Model } \\
\text { asses-sesment of the } \\
\text { students' learning } \\
\text { process object-tively } \\
\text { by using the }\end{array}$} & Observer & $75.00 \%$ & & Observer & $92.86 \%$ & \\
\hline & & Teacher & $85.71 \%$ & & Teacher & $100 \%$ & \\
\hline & & Average & $80.35 \%$ & Effective & Average & $96.43 \%$ & $\begin{array}{c}\text { More } \\
\text { Effective }\end{array}$ \\
\hline \multirow[t]{3}{*}{4} & \multirow{3}{*}{$\begin{array}{l}\text { Systematic (These } \\
\text { models are created } \\
\text { Systematic and } \\
\text { continuous use in each } \\
\text { classroom) }\end{array}$} & Observer & $75.00 \%$ & & Observer & $91.66 \%$ & \\
\hline & & Teacher & $91.66 \%$ & & Teacher & $91.66 \%$ & \\
\hline & & Average & $83.33 \%$ & Effective & Average & $91.66 \%$ & $\begin{array}{c}\text { More } \\
\text { Effective }\end{array}$ \\
\hline \multirow[t]{4}{*}{5} & \multirow{3}{*}{$\begin{array}{l}\text { Practical (This model } \\
\text { is easy to use to } \\
\text { assess student } \\
\text { learning in the } \\
\text { classroom) }\end{array}$} & Observer & $100 \%$ & & Observer & $93.75 \%$ & \\
\hline & & Teacher & $87.50 \%$ & & Teacher & $100 \%$ & \\
\hline & & Average & $97.75 \%$ & $\begin{array}{c}\text { More } \\
\text { Effective }\end{array}$ & Average & $96.88 \%$ & $\begin{array}{c}\text { More } \\
\text { Effective }\end{array}$ \\
\hline & Decision & & 89.20 & Effective & & $95.25 \%$ & $\begin{array}{c}\text { More } \\
\text { Effective }\end{array}$ \\
\hline
\end{tabular}

Based on the five criteria analysis above both in the frist Treatment and second Treatment, both of them showed that all criteria evaluated was effective. It means that teacher can apply reciprocal teaching model well in the classroom. From five criteria in the first Treatment just two criteria with beyond the $90 \%$ those are Reliability (This model can always be used in each study) and Practical (This model is easy to use to assess student learning in the classroom) and the rest under $90 \%$ point. While after improving the strategy in teaching mini volleyball game to improve students' skill in doing the down passing at the playing of mini volleyball game based on the consideration of first Treatments result was obtained all criteria of measuring the effectiveness of the reciprocal teaching model in students' perspective was effective with various students' responses on the items given both in the first and second Treatment done. For more detail can be seen in the table 6 below: 
Table 6. The Effectiveness Score of reciprocal teaching model in Students' Perspective

\begin{tabular}{|c|c|c|c|c|c|}
\hline \multirow{2}{*}{ No } & \multirow{2}{*}{ Criteria } & \multicolumn{2}{|c|}{ First Treatment } & \multicolumn{2}{|c|}{ Second Treatment } \\
\hline & & Responses & Category & Responses & Category \\
\hline 1 & $\begin{array}{l}\text { Validity (These models assess } \\
\text { student learning during the } \\
\text { learning process in the } \\
\text { classroom) }\end{array}$ & $\begin{array}{l}\text { Positive }=78.95 \% \\
\text { Negative }=21.05 \%\end{array}$ & Effective & $\begin{array}{l}\text { Positive }=90 \% \\
\text { Negative }=10 \%\end{array}$ & $\begin{array}{c}\text { More } \\
\text { Effective }\end{array}$ \\
\hline 2 & $\begin{array}{l}\text { Reliability (This model can } \\
\text { always be used in each study) }\end{array}$ & $\begin{array}{l}\text { Positive }=84.21 \% \\
\text { Negative }=15.79 \%\end{array}$ & Effective & $\begin{array}{l}\text { Positive }=100 \% \\
\text { Negative }=09 \%\end{array}$ & $\begin{array}{c}\text { More } \\
\text { Effective }\end{array}$ \\
\hline 3 & $\begin{array}{l}\text { Objective (Model asses- } \\
\text { sesment of the students' } \\
\text { learning process object- } \\
\text { tively by using the } \\
\text { guidelines appropriate) }\end{array}$ & $\begin{array}{l}\text { Positive }=89.47 \% \\
\text { Negative }=0.53 \%\end{array}$ & Effective & $\begin{array}{c}\text { Positive }=100 \% \\
\text { Negative }=0 \%\end{array}$ & $\begin{array}{c}\text { More } \\
\text { Effective }\end{array}$ \\
\hline 4 & $\begin{array}{l}\text { Systematic (These models are } \\
\text { created Systematic and } \\
\text { continuous use in each } \\
\text { classroom) }\end{array}$ & $\begin{array}{l}\text { Positive }=78.95 \% \\
\text { Negative }=1.05 \%\end{array}$ & Effective & $\begin{aligned} \text { Positive } & =87.5 \% \\
\text { Negative } & =12.05 \%\end{aligned}$ & Effective \\
\hline 5 & $\begin{array}{l}\text { Practical (This model is easy } \\
\text { to use to assess student } \\
\text { learning in the classroom) }\end{array}$ & $\begin{array}{l}\text { Positive }=78.95 \% \\
\text { Negative }=21.05 \%\end{array}$ & Effective & $\begin{array}{c}\text { Positive }=90 \%= \\
\text { Negative } 10 \%\end{array}$ & $\begin{array}{l}\text { More } \\
\text { Effective }\end{array}$ \\
\hline & Average & 82.12 & Effective & $93.50 \%$ & $\begin{array}{l}\text { More } \\
\text { Effective }\end{array}$ \\
\hline
\end{tabular}

Based on the five criteria analysis above both in the frist Treatment and second Treatment, both of them showed that all criteria of practising reciprocal teaching model in the classroom by teacher under the entire of students' response was effective. It means that the implementation of reciprocal teaching model in the classroom got postive responses from the students where the high positive response in the first treatment was in the item number 2 and 3, while in the second treatment obtained to the item number 1,2,3 and 5. The entire of students' response on reciprocal teaching model in the classroom was effective to the both treatments. While from the practical of Learning Plan and sylabus by teacher in applying this model can be explanated as follows : 
Table 7. Practical Learning Plan and Sylabus by Teachers

\begin{tabular}{clcccc}
\hline No & \multicolumn{1}{c}{ Items } & $\begin{array}{c}\text { Average } \\
\text { Rate }\end{array}$ & Category & $\begin{array}{c}\text { Average } \\
\text { Rate }\end{array}$ & Category \\
\hline 1 & Motivating students & 82.50 & Less Practical & $100 \%$ & More Practical \\
\hline 2 & $\begin{array}{l}\text { Organizing students into study } \\
\text { groups and share the work sheet }\end{array}$ & $80.26 \%$ & Less Practical & $100 \%$ & More Practical \\
\hline 3 & $\begin{array}{l}\text { The teacher presents information } \\
\text { and involved students in } \\
\text { understanding and predicting the } \\
\text { definition or concept }\end{array}$ & $90.23 \%$ & Practical & $100 \%$ & More Practical \\
\hline 4 & $\begin{array}{l}\text { Students discuss a summary with } \\
\text { the guidance of teachers }\end{array}$ & $75.69 \%$ & Less Practical & $100 \%$ & More Practical \\
\hline 5 & $\begin{array}{l}\text { Continuing the teaching learning } \\
\text { process under teachers' guidance }\end{array}$ & $85.64 \%$ & Practical & $100 \%$ & More Practical \\
\hline 6 & $\begin{array}{l}\text { Discussion and Negotiation } \\
7\end{array}$ & $80.78 \%$ & Less Practical & $100 \%$ & More Practical \\
\hline Evaluation and reflection & $95.60 \%$ & Practical & $100 \%$ & More Practical \\
\hline & Average & $84.39 \%$ & Less Practical & $100 \%$ & More Practical \\
\hline
\end{tabular}

Based on the seven criteria analysis above to measure the practicality of Learning Plan and Sylabus by Teachers In The First and Second Treatment, both of them showed that all criteria of practicallity in using the reciprocal teaching model to the subject of playing mini volleyball game to the fifth grade students from elementary schools of Koto X Singkarak sub district in Solok Regency was executed by sport teacher shiowed that in the first treatment just three item had good practicality those are item number 3, 5 and 7 and four item was still in less practicality. Meanwhile after getting revision strategy from the result of fist treatment, in the second treatment all item of Learning Plan and Sylabus practicality were more practical.

The entire of Reciprocal teaching model practicallity can be measured based on tree criteria of practicality those are General Assessment of Reciprocal teaching model, Reliability (model can always be used in every learning) and easy in the implementation of related model. The following table 8 explained about the practicallity of reciprocal teaching model.

Table 8. Practicallity of Reciprocal teaching model

\begin{tabular}{|c|c|c|c|c|c|}
\hline \multirow[b]{2}{*}{ No } & \multirow[b]{2}{*}{ Practicality Critera } & \multicolumn{2}{|c|}{ First Tretments } & \multicolumn{2}{|c|}{ Second Tretments } \\
\hline & & $\begin{array}{l}\text { Average } \\
\text { Rate }\end{array}$ & Category & $\begin{array}{l}\text { Average } \\
\text { Rating }\end{array}$ & Category \\
\hline 1 & $\begin{array}{l}\text { General Assessment of Reciprocal } \\
\text { teaching model }\end{array}$ & $88.50 \%$ & Practical & $92.50 \%$ & More Practical \\
\hline 2 & $\begin{array}{l}\text { Reliability (model can always be } \\
\text { used in every learning) }\end{array}$ & $95.00 \%$ & More Practical & $97.50 \%$ & More Practical \\
\hline 3 & $\begin{array}{l}\text { Easiness in the implementation of } \\
\text { related model }\end{array}$ & $81.82 \%$ & Practical & $98.00 \%$ & More Practical \\
\hline & Average & 89.06 & Practical & $94.30 \%$ & More Practical \\
\hline
\end{tabular}

The third criteria of practicality achievement of reciprocal teaching model has been fulfilled by collecting data from questionaire, it can be concluded that the practical reciprocal teaching model for teaching and learning of physical education and health at Elementary School on fifth grade students 
of Koto X Singkarak sub district in Solok Regency where in the first treatment the General Assessment of Reciprocal teaching model was practical with score $88.50 \%$, but in the Reliability was more practical with score $95.00 \%$ and finally in the item of Easiness in the implementation of related model was practiccal as well with $81.82 \%$. However, after revision to the second tretment the entire of practicality criteria score was $9 \%$ above with explanation of them was more practicall at all.

To determine the practicality of the learning device or teaching equipment by looking at the average score of the assessment. Based on the preceding analysis of them can be summarized description of the practicality achievement of the learning device application on a reciprocal teaching model by sport teacher in to the fifth grade student of Elementary School Koto X Singkarak can be explained by using data on the table 9 below:

Table 9. Practicallity of Learning Devices or Equipment by Teacher in The Implementation of Reciprocal teaching model

\begin{tabular}{llcccc}
\hline \multirow{2}{*}{ No } & \multirow{2}{*}{ Practicality Critera } & \multicolumn{2}{c}{ First Tretments } & \multicolumn{2}{c}{ Second Tretments } \\
\cline { 3 - 6 } & & $\begin{array}{c}\text { Average } \\
\text { Rate }\end{array}$ & Category & $\begin{array}{c}\text { Average } \\
\text { Rate }\end{array}$ & Category \\
\hline 1 & Learning Plan Practicality & $82.50 \%$ & Practical & $100 \%$ & More Practical \\
\hline 2 & Text Book/Modul Practicality & $95.24 \%$ & More Practical & $100 \%$ & More Practical \\
\hline 3 & Students Working Sheets & $90.21 \%$ & More Practical & $100 \%$ & More Practical \\
\hline \multirow{2}{*}{ Average } & $88.92 \%$ & Practical & $100 \%$ & More Practical \\
& & & &
\end{tabular}

Practicallity of learning devices or equipment by teacher in the implementation of reciprocal teaching model was measured by using three items of practicality score through analysis of curriculum expert about the learning-teaching process under this model. The result of analysis can be concluded that the Practicallity of learning devices or equipment by teacher in the implementation of reciprocal teaching model to Learning Plan 82.50 with category practice and Text Book or modul practicality was $95.24 \%$ with more practicality and student working sheets available to support the students' learning acitivities was 100\% with more practical score. Meanwhile in the second treatment the result was better than the first treatment where for all item either learning plan, text book or modul and student working sheets, they got more practical score with one hundred percentages.

The summary of all practicality items was measured to the implementation of Reciprocal teaching model to the fifth grade student of Elementary School Koto X Singkarak can be explained by using data on the table 10 as follows: 
Table 10. Summary of all Practicality Items in the Implementation of Reciprocal teaching model

\begin{tabular}{llllll}
\hline \multirow{2}{*}{ No } & \multicolumn{1}{c}{ Practicality Critera } & \multicolumn{2}{c}{ First Tretments } & \multicolumn{2}{c}{ Second Tretments } \\
\cline { 3 - 6 } & & $\begin{array}{c}\text { Average } \\
\text { Rate }\end{array}$ & Category & $\begin{array}{c}\text { Average } \\
\text { Rate }\end{array}$ & Category \\
\hline 1 & Students' activities & 32.67 & Good & 36.33 & Very Good \\
\hline 2 & Students' achievement & $95.00 \%$ & Good & $96.03 \%$ & Excellent \\
\hline 3 & $\begin{array}{l}\text { Optimalization of Students' } \\
\text { Activities In Mastering of Motoric } \\
\text { Skill of Down Passing at the Time } \\
\text { of Playing the Mini Volleyball } \\
\text { Game }\end{array}$ & $52.63 \%$ & Good & $89.47 \%$ & Very Good \\
\hline 4 & $\begin{array}{l}\text { The Effectiveness Analysis of } \\
\text { reciprocal teaching model in } \\
\text { Classroom by Teacher and Observer }\end{array}$ & $89.20 \%$ & Effective & $95.25 \%$ & More Effective \\
\hline $\begin{array}{l}\text { The Effectiveness Analysis of } \\
\text { reciprocal teaching model in } \\
\text { Classroom by Students Perspective }\end{array}$ & $82.12 \%$ & Effective & $93.50 \%$ & More Effective \\
\hline 5 & $\begin{array}{l}\text { Practicality of learnign Plan and } \\
\text { Sylabus }\end{array}$ & $84.39 \%$ & Less Practical & $100 \%$ & More Practical \\
\hline $\begin{array}{l}\text { Practicality of Reciprocal teaching } \\
\text { model }\end{array}$ & $89.06 \%$ & Practical & $94.30 \%$ & More Practical \\
\hline $\begin{array}{l}\text { Practicality of learnign devicess or } \\
\text { equipment }\end{array}$ & $88.92 \%$ & Practical & $100 \%$ & More Practical \\
\hline
\end{tabular}

Summary of all Practicality Items in the Implementation of Reciprocal teaching model with categorize into Fifth attainment to measure the effective model on students' improvement of their down passing skill at the time of playing the mini volleyball game to the fifth grade student of Elementary School Koto X Singkarak showed that fifth criteria measured provide a good achievement. It can be concluded that the reciprocal teaching model is more effective for teaching and learning of physical education and health at Elementary School in the fifth grade students Koto X Singkarak District of Solok Regency.

Development of a model reciprocal showed that in the game of mini volleyball student loves to spend his time playing and practicing in the field to improve their motor movements in accordance with the instructions. In this way students can improve their skills to play mini volleyball better, especially for the mastery of down passing with their mutual task of observing when the other train in the group task. According to Topping (2005), train motor movements closely associated with a given time during practice and giving instruction also contributes importantly to improve the students' enthusiasm for learning.

The observational studies in a reciprocal type of cooperative learning indicates that children in structured group clarifications give explanation that trains with their colleagues will be better than train alon because there is positive input that they can get from their colleagues when observe histraining in group work (Gillies, 2003). In this study, sharing their duties to observe and practice can only be obtained from the model of reciprocal learning. With this model the student shall provide information related to the impact of their training course by providing positive feedback that directly gives affect to their motivation to become more actively practicing under peer observation group and guide instruction from teachers who all will share training techniques for improvement in the next meeting. 
While this is still considerably between students who have not been actively involved in the learning process, it is likely due to the limited time of trainig given by teacher because adjacent to breaking time or because too much subject matter that they have learned that day makes them decline in motivation, because they practiced sport in the last hour, so it is difficult to focus the power of memory. According to Kirschner, Sweller, \& Clark (2006), states that in the focused learning environment, working memory is used to find solutions to problems and information and consequently can not be used to learn too long. In addition, Moreno (2004) concluded that the growth of the body in a variety of studies show that students who learn more intensive through strictly guidance, the impact of learning will be different with students who learn without strictly guidance or be left alone, they learn on their own without guidance. Learning without strictly guidance of a teacher, obviously can help students and friends in the group will be working hard to find ways to quickly master the technique of the game from observations of their peers when they practice. In this way placing students in high demand for practice and master the techniques of a right movement in the playing volleyball games quickly. Self regulated study without guidance, typically encourage students to learn in a group to be sharing information (reciprocal) of the results of their observation in improving their motor movements were deemed less appropriate technique. The benefits of selflearning through reciproacal learning model are 1) students can set the time of their own learning (for example Who will start practicing? How to practice?, How should divide their time studying and practicing in group work?), and 2) learn more to master in motor-oriented skills. Cognitive demands could burden the working memory and negative impact because it affects the student's learning style. In addition, the function of the working group model enables reciprocal learning between colleagues observe each other's members then share feedback and guidance related to future improvements of their training techniques.

From the results of this research showed that the development model of reciprocal was very effective in improving student passing down skills in the game of mini volleyball at elementary school of SDN Koto Singkarak Solok. The success of reciprocal learning model was supported by the competence of teachers to provide instructions and give adequate feedback when students practice, giving observations focus in assessing the movement technique of down passing correctly and mutually discuss and consult to fix the mistakes made in the previous exercise either with teachers or colleague. Therefore, defining the role of teachers with provision of practice and observation tasks in a model reciprocal clearly give a positive influence to increase the motivation of student to learn and at the same time passing the mastery of movement technique of down passing correctly in the playing of mini volleyball game.

From the findings, it seemed there was little limiation is still not optimal the implementation of reciprocal learning model that looks not optimallnya the quality of feedback and instructions are carried out, and it needs further research. Improving the quality of feedback and giving sustainable instruction in the use of learning reciproacal techniques to improve studetns' learning outcomes and mastery in the motor movement of down passing quickly and completely when palying the mini volleyball. It can be done by supporting with a good system of exercise. Consultation and feedback each other among group members can give a positive contribution either to you and your peers.

From the research findings was obtained that by doing the development of a reciprocal model can increase the students' activity, academic achievement and optimization of the student motor movement in the technique of down passing in the playing of mini volleyball game. Besides reciproacal learning model which is developed also proved effective in the classroom and in the field either carried out by teachers and students, both of them give positive response. In terms of the success in the mastery of techniques of down pasing in the playing volleball reached $89.20 \%$ to $92.25 \%$, in terms of the effectiveness of the model to build the students'spirit to exercises was $8212 \%$ to $93.50 \%$, the practicality of the model seen from the syllabus and lesson plan was $84.39 \%$ up to $100 \%$, the practicality of the implementation of the exercise with reciproacal was $89.06 \%$ to $94.30 \%$ and the 
practicality of the model provided with teaching materials was $88.92 \%$ to $100 \%$. The results of this trial showed that the development of reciprocal learning model aims to improve the ability of students enable to do the righ passing down in the playing of mini- volleyball and it was proved very effective. This suggests that the success of the learning activities of mini volleyball game heavily influenced by a reciprocal learning model with a peers teaching model in the group. In tutor literature of learning with peers, suggesting that this method can enable knowledge within students and inert (Bruffee, 1973, Daiute \& Dalton, 1993, Parr \& Townsend, 2002) On the other hand, practice is an attempt to consolidate learning (Parr \& Townsend, 2002).

While the results of this study contrast with Cohen, Kulik, \& Kulik (1982) arguments which states that the frequency of the feedback whether requested or not remains positively correlated to the students' motivation to practice. But in this study indicate that the use of a learning reciprocal model in peers observing and assessing each other at the group is realy important as indicators that affect the proficiency of students in mastering the technique of down passing correctly in the game of volleyball at school. It means that both teachers and obsever by peers obviously would encourage its members to practice more seriously, especially when given positive feedback, it will increasingly affect student persistence to train in reaching their master in the correct technique of down passing quickly. Unlike when they get negative feedback from observations of peers, it is having some effect on decreasing the interest and enthusiasm of their workout. This is what distinguishes these findings by arguing Cohen.

Analysis of the interaction of exercise and behavior of students showed that students who mutually observe and assess the results of the exercise in the working group will spend more time to learn and to assess and observe that indirectly will take these experiences to improve their practice. The learning model mutually observe and assess a friend while exercising in a group it is possible that students can master the technique of exercise of down passing in the game of volleyball quickly because of the totality of the time of exercise carried out optimally, the practice and observation the right movement to fix fault movement technique of down passing in the previous exercise. In essence, reciprocal learning model is a model of mutual learning and observation exercises set tasks. The amount of time spent on this activity for a long time and the longer practicing and observing will be a positive impact on the future success of the exercise.

\section{Conclusions}

The conclusions of this reserach are to the implementation of reciprocal teaching model to the fifth grade student of Elementary School Koto X Singkarak covered development of modul, learning plan, students' working sheets, practicality of modul, optimalization of students activities test and student achivement test of down passing skill in the playing of mini volleyball game subject have been valid and feasible to be applied by sport teacher in order to increase student motoric skill of down passing in plyaing the mini volleyball game. To be suggested to all sport teachers in Soloc region would like to apply the reciprocal teaching model in the classroom when teacing the subject of mini volleyball game in order to be easier to enghance students' motoric skill of down passing into the volleyball game.

\section{Acknowledgments}

This study was supported by State University of Padang. We thanks so much to our colleagues of Zelhendri Zein, M.Pd who provided insight and expertise that greatly contribution to the research analysis. We also thanks a lot to Reflianto, M.Pd who help us in the particular technique, methodology and comments for greatly improvement of this paper. 


\section{References}

Bloom, B. S. (1956). Taxonomy of Educational Objectives : The Classification of Educational Goals, Handbook I Cognitive Domain. New York: Longmans, Green and Co.

Briggs., G. R. M. \&. (1977). Principles of Instructional Design. New York: Holt Rinchart and Winston.

Bruffee, K. a. (1973). Collaborative learning: Some practical models. College English, 34(5), 634-643. https://doi.org/10.2307/375331

Cohen, P. A., Kulik, J. A., \& Kulik, C.-L. C. (1982). Educational Outcomes of Tutoring: A Metaanalysis of Findings. American Educational Research Journal, 19(2), 237-248. https://doi.org/10.3102/00028312019002237

Creswell W John. (2014). Research Design, Qualitative, Quantitative and Mixed Methods Approaches (4th ed.). SAGE Publication, Inc.

Daiute, C., \& Dalton, B. (1993). Between Children Collaboration to Write : Learning Can Novices Be Masters ? Cognition and Instruction, 10(4), 281-333. https://doi.org/10.1207/s1532690xci1004

Dougiierty, N., \& Bonanno, D. (1979). Contemporary approaches to the teaching of physical education. Minneapolis: MN: Burgess.

Gillies, R. M. (2003). Structuring cooperative group work in classrooms. International Journal of Educational Research, 39(1-2), 35-49. https://doi.org/10.1016/S0883-0355(03)00072-7

Kirschner, P. A., Sweller, J., \& Clark, R. E. (2006). Why Minimal Guidence During Instruction Does Not Work: An Analysis of the Failure Of Constructivist, Problem-Based, Experiential and Inquiry-Based Teaching. Educational Psycologist, 41(2), 75-86. https://doi.org/10.1207/ s15326985ep4102_1

Moreno, R. (2004). Decreasing Cognitive Load for Novice Students: Effects of Explanatory versus Corrective Feedback in Discovery-Based Multimedia. Instructional Science, 32(1/2), 99-113. https://doi.org/10.1023/B:TRUC.0000021811 .66966.1d

Parr, J. M., \& Townsend, M. A. R. (2002). Environments, processes, and mechanisms in peer learning. International Journal of Educational Research, 37(5), 403-423. https://doi.org/10.1016/S08830355(03)00013-2

Topping, K. J. (2005). Trends in peer learning. Educational Psychology, 25(6), 631-645. https://doi.org/10.1080/01443410500345172

Yunus, M. (1992). Olahraga Pilihan Bola Voli. Jakarta: Depdikbud. 